\title{
ANTIOXIDANT EVALUATION AND HEAVY METALS ACCUMULATION OF CAPSICUM ANNUUM L. CULTIVARS
}

\author{
Azizuddin, Kiran and Kousar Yasmeen \\ Department of Chemistry, Federal Urdu University of Arts, Science and Technology, \\ Karachi-75300, Pakistan
}

Keywords: Capsicum annuum, Chilli, Dandi, Ghotki, German, Antioxidant activity

\begin{abstract}
Capsicum annuum L. commonly known as chilli provides dietary fibers, minerals and vitamins. In this study, three different chilli cultivars commonly named as Dandi, Ghotki and German were studied for the determination of physico-chemical properties, antioxidant activity and metal content. German showed maximum nutritional components as compared to Ghotki and Dandi such as TA (0.43 \%), TDS (1.95 g/l), TSS (1.29 ${ }^{\circ}$ Brix) and TSC (1108.72 mg/100 g). Dandi showed higher TPC $(6286.60 \mathrm{mg} / 100 \mathrm{~g})$ and TFC $(258.88 \mathrm{mg} / 100 \mathrm{~g})$ with significant antioxidant activity through DPPH (37.27\% inhibition) and RPA $(1134.80 \mathrm{mg} / 100 \mathrm{~g})$. Fe was found in sufficient amount among chilli cultivars and metals accumulation was within the standard safe limits.
\end{abstract}

\section{Introduction}

Vegetables are an important part of the diet due to a great source of phyto-nutraceuticals, minerals, dietary fibers and phytochemicals (Singh and Devi 2015). Vegetables in the food are linked with general health including development of gastrointestinal healthiness, coronary illness, stroke, diabetes, gastric ulcer and other prolonged disorders. Diet with high portion of vegetables decreases the risk of certain cardiovascular disorders (Dias 2012).

Heavy metals have relatively high density and are toxic at low quantities. They can enter into the body systems through diet, drinking water and air. In human body, some heavy metals e.g. $\mathrm{Cu}$, $\mathrm{Se}$ and $\mathrm{Zn}$ are important to adjust the metabolic processes. In case of higher amount, they are dangerous for human health because of their bioaccumulation inside the body. $\mathrm{Cd}$ increase accumulation cause phytotoxicity to the plants and then ultimately to food chain whereas growth process of plants is affected ( $\mathrm{Pal}$ et al. 2012). Extreme concentration of $\mathrm{Cu}$ can interrupt many physiological processes including DNA alterations, enzyme action and then result in growth inhibition of plants (Islek and Unal 2015). Fe is an important component for plants and humans. Iron has comparatively great WHO level in foods (Nkansah and Amoako 2010). Pb is a highly toxic metal and its exposure cause permanent brain damage, severe anemia, reproductive problems and neurological disorders (Wani et al. 2015). Deficiency of $\mathrm{Zn}$ is the cause of hypogonadism and growth retardation. It also affects metabolism and growth hormone $(\mathrm{GH})$.

Capsicum anпиит L. (chilli) is a popular vegetable belonging to Solanaceae. It is used as source of nourishments and spice. Furthermore, it has been used for several years as a source of pigments to change the colour of food products. Fresh chilli is a good source of different vitamins including vitamin $\mathrm{E}$ and $\mathrm{C}$ as well as provitamin $\mathrm{A}$ and carotenoid components with well-known beneficial antioxidant properties (Arnnok et al. 2012).

The main objective of this study was to evaluate and compare the physico-chemical properties, antioxidant activities, total phenolic (TPC) and total flavonoid (TFC) contents, and heavy metals accumulation in three cultivars of chilli named as Dandi, Ghotki and German, which were grown in same the environmental and agronomic conditions.

*Author for correspondence: <azizpobox1@yahoo.com>. 


\section{Material and Methods}

The cultivars of red chilli commonly known as German, Ghotki and Dandi were cultivated and grown under similar climatic conditions in a farm at Wadh, district Khuzdar (Pakistan) in June 2016, and the ripened and matured red chilli cultivars were collected in September 2016. They were dried then packed in polyethylene bags and brought to the laboratory, Department of Chemistry, Federal Urdu University of Arts, Science and Technology, Karachi, Pakistan. The chilli samples were selected uniformly on the basis of their size and colour as well as their outer skin which was free from any microbial and physical damages. They were grouped into different sets for further evaluation.

All the samples were washed and cleaned with tap water then with distilled water and dried at $32^{\circ} \mathrm{C}$. They were cut into small pieces. Five gram of each cultivar was crushed with the help of motor and pastel, then soaked in water and methanol $(100 \mathrm{ml})$ separately with stirring on magnetic stirrer (78-1, China) for $60 \mathrm{~min}$. Sample extracts $(5 \% \mathrm{w} / \mathrm{v})$ were filtered with the help of Whatman filter paper. Methanolic extracts were used for the determination of chlorophyll a, chlorophyll $b$, total carotenoids, TPC, TFC and antioxidant activity whereas water extracts were used for the estimation of titratable acidity, TSS, TDS, $\mathrm{pH}$, conductance and TSC.

For metals $(\mathrm{Fe}, \mathrm{Cu}, \mathrm{Cd}, \mathrm{Zn}, \mathrm{Pb}$ and $\mathrm{Ni})$; analysis samples of chilli were washed, cleaned with tap water, then with deionized water and dried at ambient temperature. The $50 \mathrm{~g}$ of each variety of chilli was weighed into a beaker on an electronic balance then placed in an oven at $150^{\circ} \mathrm{C}$ for 5-6 hrs until the weight of the sample became constant as the moisture decreased. After that, 15-20 ml of $\mathrm{HNO}_{3}$ and 5-8 $\mathrm{ml}$ of $35 \% \mathrm{H}_{2} \mathrm{O}_{2}$ solution were added into the sample beaker and it was placed on a hot plate with continued stirring for digestion purpose until the fumes of the sample became colorless from colored fumes and all the sample matrix became dissolved. After that, sample solution was filtered through Whatman filter paper and solution was made up to $50 \mathrm{ml}$ in volumetric flask using deionized water and analyzed on flame atomic absorption spectrophotometer [(FAAS) PE AAnalyst 700, Singapore].

Moisture content and total dry matter were determined using ISI official method (1984) whereas ash content, titratable acidity (TA) and total sugar content (TSC) were analyzed by using AOAC official methods (1990). The $\mathrm{pH}$ was observed using $\mathrm{pH}$ meter whereas TDS and conductivity were noted with the help of meter. Total soluble solids (TSS) were estimated by using the method of BIS IS (1993) with the help of refractometer (KRÜSS DR 6200, Germany) and represented as ${ }^{\circ}$ Brix glucose. Chlorophyll a $\left(\mathrm{C}_{\mathrm{a}}\right)$, chlorophyll $\mathrm{b}\left(\mathrm{C}_{\mathrm{b}}\right)$ and total carotenoids content were determined by the method of Dere et al. (1998) using UV-visible spectrophotometer.

Total phenolic content (TPC) was determined using the method described by Velioglu et al. (1998). Gallic acid was used as standard and calibration curve was plotted (100-1000 mg/l, $\mathrm{r}^{2}=$ 0.608). Total flavonoid content (TFC) was also analyzed by the method described by Zhishen et al. (1999). The concentration of TFC was evaluated by comparison of standard with known concentration of catechin $\left(20-200 \mathrm{mg} / \mathrm{l}, \mathrm{r}^{2}=0.951\right)$. Antioxidant potential was obtained by using DPPH (2,2-diphenyl-1-picrylhydrazyl) assay (De Ancos et al. 2002). The percent inhibition of DPPH radical was determined. Antioxidant activity was also determined by reducing power assay (Jayanthi and Lalitha 2011). The calibration curve of different concentration of ascorbic acid as standard was used $\left(100-1000 \mathrm{mg} / \mathrm{l}, \mathrm{r}^{2}=0.780\right)$ to determine antioxidant activity.

All the parameters were analyzed in triplicates, and results were represented as Mean \pm SEM. The data were statistically analyzed by ANOVA on Minitab 16 and Tukey's HSD were also applied in order to find significant differences at $95 \%$ confidence level $(\mathrm{p} \leq 0.05)$. 


\section{Results and Discussion}

Results presented in Table 1 showed that German has the maximum average weight $(6.69 \mathrm{~g})$ with maximum length $(11.68 \mathrm{~cm})$, volume $\left(15.04 \mathrm{~cm}^{3}\right)$ and diameter $(4.10 \mathrm{~cm})$ whereas the minimum weight $(1.23 \mathrm{~g})$, length $(3.30 \mathrm{~cm})$ and volume $\left(5.02 \mathrm{~cm}^{3}\right)$ were in Dandi.

Titratable acidity (TA) was observed higher in German (0.43) as compared to Ghotki (0.34 $\%)$ and Dandi $(0.13 \%)$. This resulted in a gradual increase in $\mathrm{pH} 4.73,5.00$ and 6.62, respectively (Table 2). These results showed a strong and inverse relation between $\mathrm{pH}$ and TA. It has been reported that microorganisms, especially lactic acid bacteria have ability to produce organic acids, which cause an increase in TA and simultaneous decrease in $\mathrm{pH}$ values (Mangaraj et al. 2001).

Table 1. Physical attributes of different varieties (Dandi, Ghotki and German) of chilli.

\begin{tabular}{|c|c|c|c|c|}
\hline \multicolumn{2}{|c|}{ Parameter (unit) } & $\begin{array}{c}\text { Dandi } \\
\text { (mean } \pm \text { S.E.M.) }\end{array}$ & $\begin{array}{c}\text { Ghotki } \\
(\text { mean } \pm \text { S.E.M. })\end{array}$ & $\begin{array}{c}\text { German } \\
\text { (mean } \pm \text { S.E.M.) }\end{array}$ \\
\hline \multirow{3}{*}{ Size } & Length $(\mathrm{cm})$ & $3.30 \pm 0.05^{\mathrm{C}}$ & $7.70 \pm 0.21^{\mathrm{B}}$ & $11.68 \pm 0.32^{\mathrm{A}}$ \\
\hline & Diameter $(\mathrm{cm})$ & $2.00 \pm 0.01^{\mathrm{B}}$ & $1.30 \pm 0.01^{\mathrm{C}}$ & $4.10 \pm 0.00^{\mathrm{A}}$ \\
\hline & Volume $\left(\mathrm{cm}^{3}\right)$ & $5.02 \pm 0.03^{\mathrm{C}}$ & $10.00 \pm 0.02^{\mathrm{B}}$ & $15.04 \pm 0.02^{\mathrm{A}}$ \\
\hline \multicolumn{2}{|c|}{ Weight $(g)$} & $1.23 \pm 0.01^{\mathrm{C}}$ & $2.12 \pm 0.05^{\mathrm{B}}$ & $6.69 \pm 0.02^{\mathrm{A}}$ \\
\hline \multicolumn{5}{|c|}{ Colour (Reddish brown) } \\
\hline
\end{tabular}

S.E.M. = Standard error of the mean of three replicates. A-C values in different rows with various superscripts are of significant differences and were justified at the confidence level of $95 \%$ (ANOVA) by Tukey's HSD $(\mathrm{p} \leq 0.05)$.

The highest amount of TDS was observed in German (1.95) than Ghotki (1.65) and Dandi $(1.58 \mathrm{~g} / \mathrm{l})$. These results were directly correlated to the conductance that certain species were present having solvation ability. Therefore, the highest conductance was observed in German (3.28) as compared to Ghotki (2.75) and Dandi (2.63 mS) (Table 2). The maximum moisture content was observed in German (17.91) as compared to Ghotki (15.64) and Dandi (13.93\%) (Table 2). Chilli varieties were subjected for evaluation in dry form that's why represented very low moisture content. The maximum ash content was detected in Dandi (6.54) than German (6.18) and Ghotki $(6.10 \%)$ (Table 2), indicating all varieties contain approximately similar amount of inorganic residue. Total soluble solids (TSS) describes vegetable maturity index. It includes different sugars i.e. glucose, fructose, sucrose, etc. It was found higher in German (1.29) as compared to Ghotki (1.18) and Dandi $\left(1.01^{\circ}\right.$ Brix). Similar trend was found for TSC in German (1108.72), Ghotki (677.96) and Dandi $(284.12 \mathrm{mg} / 100 \mathrm{~g})$. The highest amount of chlorophyll a was observed in Ghotki (1.36) as compared to Dandi (1.29) and German (1.18 ppm). Similarly chlorophyll b was also found greater in Ghotki (2.97) than Dandi (2.85) and German (2.53 ppm). Chlorophyll pigment provides several health benefits and also responsible for green colour in vegetables. Ghotki represented the maximum carotenoid content (656.23) whereas least amount in Dandi (520.87 ppm) (Table 2). Previous studies reported that red colour of chilli is due to the presence of carotenoids and intake of diet containing its high amount which helps in reduction of chronic disorders (Arimboor et al. 2015). 
Table 2. Chemical composition of different varieties (Dandi, Ghotki and German) of chilli.

\begin{tabular}{lccc}
\hline \multicolumn{1}{c}{ Parameter (unit) } & $\begin{array}{c}\text { Dandi } \\
\text { (mean } \pm \text { S.E.M.) }\end{array}$ & $\begin{array}{c}\text { Ghotki } \\
(\text { mean } \pm \text { S.E.M. })\end{array}$ & $\begin{array}{c}\text { German } \\
(\text { mean } \pm \text { S.E.M. })\end{array}$ \\
\hline pH & $6.62 \pm 0.01^{\mathrm{A}}$ & $5.00 \pm 0.01^{\mathrm{B}}$ & $4.73 \pm 0.00^{\mathrm{C}}$ \\
Titratable acidity (TA) (\%) & $0.13 \pm 0.00^{\mathrm{C}}$ & $0.34 \pm 0.00^{\mathrm{B}}$ & $0.43 \pm 0.01^{\mathrm{A}}$ \\
Total dissolved solids (TDS) (g/l) & $1.58 \pm 0.01^{\mathrm{C}}$ & $1.65 \pm 0.01^{\mathrm{B}}$ & $1.95 \pm 0.02^{\mathrm{A}}$ \\
Conductance (mS) & $2.63 \pm 0.01^{\mathrm{C}}$ & $2.75 \pm 0.01^{\mathrm{B}}$ & $3.28 \pm 0.04^{\mathrm{A}}$ \\
Moisture content (\%) & $13.93 \pm 0.13^{\mathrm{C}}$ & $15.64 \pm 0.19^{\mathrm{B}}$ & $17.91 \pm 0.12^{\mathrm{A}}$ \\
Total dry matter (\%) & $86.07 \pm 0.11^{\mathrm{A}}$ & $84.36 \pm 0.05^{\mathrm{B}}$ & $82.09 \pm 0.02^{\mathrm{C}}$ \\
Ash content $(\%)$ & $6.54 \pm 0.12^{\mathrm{A}}$ & $6.10 \pm 0.84^{\mathrm{C}}$ & $6.18 \pm 0.13^{\mathrm{B}}$ \\
Total organic matter (\%) & $93.46 \pm 2.15^{\mathrm{C}}$ & $93.90 \pm 1.58^{\mathrm{A}}$ & $93.82 \pm 1.92^{\mathrm{B}}$ \\
Total soluble solids (TSS) $\left({ }^{\circ} \mathrm{Brix}\right)$ & $1.01 \pm 0.01^{\mathrm{C}}$ & $1.18 \pm 0.02^{\mathrm{B}}$ & $1.29 \pm 0.01^{\mathrm{A}}$ \\
Total sugar content (TSC) $(\mathrm{mg} / 100 \mathrm{~g})$ & $284.12 \pm 0.39^{\mathrm{C}}$ & $677.96 \pm 0.50^{\mathrm{B}}$ & $1108.72 \pm 0.27^{\mathrm{A}}$ \\
Chlorophyll a (ppm) & $1.29 \pm 0.04^{\mathrm{B}}$ & $1.36 \pm 0.01^{\mathrm{A}}$ & $1.18 \pm 0.00^{\mathrm{C}}$ \\
Chlorophyll b (ppm) & $2.85 \pm 0.03^{\mathrm{B}}$ & $2.97 \pm 0.00^{\mathrm{A}}$ & $2.53 \pm 0.00^{\mathrm{C}}$ \\
Total carotenoids (ppm) & $520.87 \pm 1.10^{\mathrm{C}}$ & $656.23 \pm 0.54^{\mathrm{A}}$ & $646.63 \pm 0.58^{\mathrm{B}}$ \\
\hline
\end{tabular}

S.E.M. = Standard error of the mean of three replicates. A-C values in different rows with various superscripts are of significant differences and were justified at the confidence level of $95 \%$ (ANOVA) by Tukey's HSD $(\mathrm{p} \leq 0.05)$.

Phenolic compounds are key components that perform a vital role in the reproduction and growth of plants as well as provide protection against predators and pathogens (Lattanzio et al. 2006). Chilli adds great quantity of phenolic compounds in the vegetables (Kevers et al. 2007). Similarly, TPC was observed in higher amount in all chilli varieties. The Dandi variety represented higher TPC (6286.60) as compared to Ghotki (3000.40) and German (1614.46 mg/100 g) (Table 3). Flavonoids represent a huge group of polyphenolic compounds. They are very beneficial as an antiarthritic agent, antimicrobial agent, antiulcer agent and antiangiogenic agent (Gurnani et al. 2016). TFC was also determined in chilli varieties in which higher quantity was observed in Dandi (258.88) as compared to Ghotki (199.98) and German (194.22 mg/100 g) (Table 3).

Table 3. Antioxidant analysis of different varieties (Dandi, Ghotki and German) of chilli.

\begin{tabular}{lccc}
\hline Parameter (Unit) & $\begin{array}{c}\text { Dandi } \\
(\text { mean } \pm \text { SEM.) }\end{array}$ & $\begin{array}{c}\text { Ghotki } \\
(\text { mean } \pm \text { SEM.) }\end{array}$ & $\begin{array}{c}\text { German } \\
\text { (mean } \pm \text { SEM.) }\end{array}$ \\
\hline Total phenolic content (TPC) $(\mathrm{mg} / 100 \mathrm{~g})$ & $6286.60 \pm 22.50^{\mathrm{A}}$ & $3000.40 \pm 20.00^{\mathrm{B}}$ & $1614.46 \pm 6.31^{\mathrm{C}}$ \\
Total flavonoid content (TFC) $(\mathrm{mg} / 100 \mathrm{~g})$ & $258.88 \pm 4.01^{\mathrm{A}}$ & $199.98 \pm 2.20^{\mathrm{B}}$ & $194.22 \pm 2.84^{\mathrm{C}}$ \\
$\begin{array}{l}\text { DPPH radical scavenging assay }(\% \\
\text { inhibition at 0.1 mM conc.) }\end{array}$ & $37.27 \pm 4.18^{\mathrm{A}}$ & $33.12 \pm 1.37^{\mathrm{B}}$ & $32.37 \pm 1.35^{\mathrm{C}}$ \\
Reducing power assay (RPA) $(\mathrm{mg} / 100 \mathrm{~g})$ & $1134.80 \pm 4.21^{\mathrm{A}}$ & $658.34 \pm 19.09^{\mathrm{B}}$ & $397.02 \pm 5.42^{\mathrm{C}}$ \\
\hline
\end{tabular}

S.E.M. = Standard error of the mean of three replicates. A-C values in different rows with various superscripts are of significant differences and were justified at the confidence level of $95 \%$ (ANOVA) by Tukey's HSD $(\mathrm{p} \leq 0.05)$. 
DPPH radical scavenging assay was performed on chilli varieties for determination of their antioxidant activities. It was observed that Dandi represented the maximum inhibition (37.27) as compared to Ghotki (33.12) and German (32.37\%) (Table 3). No significant difference was observed among chilli varieties at $95 \%$ confidence level $(\mathrm{p} \leq 0.05)$. In this study, a relationship was observed between antioxidant activity and phenolic and flavonoid contents. Earlier research showed that these phenolic and flavonoid contents are responsible for antioxidant activities of chilli, therefore a linear correlation was observed between these constituents and antioxidant activity of chilli (Ghasemzadeh et al. 2012).

Reducing power assay (RPA) was also performed in order to determine antioxidant activity of three varieties of chilli. Dandi showed higher antioxidant potential (1134.80) as compared to Ghotki (658.34) and German (397.02 mg/100 g) (Table 3). A significant difference was observed among these varieties at $95 \%$ confidence level $(\mathrm{p} \leq 0.05)$. Srideepthi et al. (2017) reported that chilli varities showed strong reducing power due to presence of phenolic components, which help in radical scavenging process.

Chilli contaminated with heavy metals in food may cause accumulation of metals in human body and resulted in different health problems. The heavy metals may spread and contaminate the fruits, vegetables and plants through water, soil and air during different industrial processes. The concentration of heavy metals was determined on three chilli varieties and the results are presented in Table 4.

Table 4. Heavy metals (ppm) in different varieties (Dandi, Ghotki and German) of chilli.

\begin{tabular}{lcccc}
\hline $\begin{array}{l}\text { Heavy } \\
\text { metals }\end{array}$ & $\begin{array}{c}\text { Dandi } \\
\text { (mean } \pm \text { S.E.M. })\end{array}$ & $\begin{array}{c}\text { Ghotki } \\
(\text { mean } \pm \text { S.E.M. })\end{array}$ & $\begin{array}{c}\text { German } \\
\text { (mean } \pm \text { S.E.M. })\end{array}$ & $\begin{array}{c}\text { Safe limits } \\
\text { (WHO/FAO and US EPA) }\end{array}$ \\
\hline $\mathrm{Cd}$ & $0.035 \pm 0.0019^{\mathrm{A}}$ & $0.015 \pm 0.0010^{\mathrm{B}}$ & $0.013 \pm 0.0010^{\mathrm{C}}$ & 1.0000 \\
$\mathrm{Cu}$ & $0.124 \pm 0.0159^{\mathrm{B}}$ & $2.309 \pm 0.1750^{\mathrm{A}}$ & $0.028 \pm 0.0122^{\mathrm{C}}$ & 30.0000 \\
$\mathrm{Fe}$ & $1.495 \pm 0.1060^{\mathrm{B}}$ & $1.968 \pm 0.0480^{\mathrm{A}}$ & $1.232 \pm 0.1341^{\mathrm{C}}$ & 48.0000 \\
$\mathrm{Ni}$ & $\mathrm{BDL}$ & $\mathrm{BDL}$ & $\mathrm{BDL}$ & 0.9050 \\
$\mathrm{~Pb}$ & $0.550 \pm 0.0380^{\mathrm{A}}$ & $0.521 \pm 0.0310^{\mathrm{B}}$ & $0.408 \pm 0.0121^{\mathrm{C}}$ & 2.0000 \\
$\mathrm{Zn}$ & $0.318 \pm 0.0250^{\mathrm{B}}$ & $0.345 \pm 0.0089^{\mathrm{A}}$ & $0.151 \pm 0.0129^{\mathrm{C}}$ & 60.0000 \\
\hline
\end{tabular}

$\mathrm{BDL}=$ Below detection limit. S.E.M. = Standard error of the mean of three replicates. A-C values in different rows with various superscripts are of significant differences and were justified at the confidence level of 95 $\%$ (ANOVA) by Tukey's HSD ( $\mathrm{p} \leq 0.05)$.

The highest amount of Cd with slight difference was observed in Dandi (0.035) than Ghotki $(0.015)$ and German $(0.013 \mathrm{ppm})$ while the $\mathrm{Cu}$ concentration in Ghotki (2.309) was relatively high. The highest Fe concentration was found in Ghotki (1.968) than Dandi (1.495) and German (1.232 ppm) whereas the higher amount of $\mathrm{Pb}$ was found in Dandi (0.550) second highest in Ghotki $(0.521)$ and lowest in German $(0.408 \mathrm{ppm})$. The higher amount of $\mathrm{Zn}$ was observed in Ghotki (0.345), second highest in Dandi (0.318) and lowest in German (0.151 ppm).

It was also observed that both $\mathrm{Cd}$ and $\mathrm{Pb}$ share a similar trend whereas $\mathrm{Cu}, \mathrm{Fe}$ and $\mathrm{Zn}$ represent similar trends in these varieties of chilli. Nickel $(\mathrm{Ni})$ was found below detection limit. All the observed values were below than the safe limit as proposed by standard values (US EPA 2010, Bassey et al. 2014). Therefore, these chilli varieties were very beneficial consumption.

It may be concluded that German had different appearance and showed higher titratable acidity and total sugar content whereas Ghotki represented higher number of total carotenoids. The 
results showed that these varieties of chilli had considerable number of phenolic components as natural antioxidants, contributing in good antioxidant capacity. Dandi showed higher antioxidant activity than German and Ghotki through DPPH and reducing power assays, which was correlated with higher amount of phenolic and flavonoid contents. Fe was found in higher amount in chilli varieties in contrast with other metals. It was also noted that metals concentration was found below than standard safe limits. Therefore, intake of these chilli varieties was not harmful for human health. The results clearly indicated that these chilli varieties were highly beneficial for human health due to presence of high phenolic and flavonoid contents with strong antioxidant capacity as well as Fe concentration especially Dandi.

\section{References}

AOAC 1990. Official methods of analysis; In: Association of official analytical chemists (15th Ed.) Vols I and II. Washington, DC.

Arimboor R, Natarajan RB, Menon KR, Chandrasekhar LP and Moorkoth V 2015. Red pepper (Capsicum aпnиит) carotenoids as a source of natural food colors: analysis and stability-a review. J. Food Sci. Tech. 52(3): 1258-1271.

Arnnok P, Ruangviriyachai C, Mahachai R, Techawongstien S and Chanthai S 2012. Determination of total phenolics and anthocyanin contents in the pericarp of hot chilli pepper (Capsicum annuum L.). Int. Food Res. J. 19(1): 235-243.

Bassey FI, Iwegbue CMA, Obi-Iyeke GE, Tesi GO, Rotu AR, Gobe OA and Tsafe AI 2014. Heavy metals in soils and tomatoes grown in urban fringe environment in Asaba, delta state, Nigeria. Niger. J. Basic Appl. Sci. 22: 27-31.

BIS IS 13815 1993. Fruit and vegetables products determination of soluble solids content refractometric method, New Delhi, India, Bureau of Indian Standard Publisher.

De Ancos B, Sgroppo S, Plaza L and Cano MP 2002. Possible nutritional and health-related value promotion in orange juice preserved by high-pressure treatment. J. Sci. Food Agri. 82: 790-796.

Dere S, Gunes T and Sivaci R 1998. Spectrophotometric determination of chlorophyll-a, b and total carotenoid contents of some algae species using different solvents. Turk. J. Bot. 22: 13-17.

Dias JS 2012. Nutritional quality and health benefits of vegetables: A review. Food Nutr. Sci. 3: 1354-1374.

Ghasemzadeh A, Azarifar M, Soroodi O and Jaafar HZE 2012. Flavonoid compounds and their antioxidant activity in extract of some tropical plants. J. Med. Plants Res. 6(13): 2639-2643.

Gurnani N, Guptab M, Mehtaa D and Mehta BK 2016. Chemical composition, total phenolic and flavonoid contents, and in vitro antimicrobial and antioxidant activities of crude extracts from red chilli seeds (Capsicum frutescens L.). J. Taibah Uni. Sci. 10: 462-470.

ISI 1984. Handbook of food analysis, VIII-determination of moisture in dehydrated vegetables. New Delhi, India, Bureau of Indian Standards, p. 12.

Islek C and Unal BT 2015. Copper toxicity in Capsicum annuит: superoxide dismutase and catalase activities, phenolic and protein amounts of in-vitro-grown plants. Pol. J. Environ. Stud. 24(6): 24412445.

Jayanthi P and Lalitha P 2011. Reducing power of the solvent extracts of Eichhornia crassipes (Mart.) Solms. Int. J. Pharm. Pharm. Sci. 3: 126-128.

Kevers C, Falkowski M, Tabart J, Defraigne JD, Dommes J and Pincemail J 2007. Evolution of antioxidant capacity during storage of selected fruits and vegetables. J. Agric. Food Chem. 55(21): 8596-8603.

Lattanzio V, Lattanzioand VMT and Cardinali A 2006. Role of phenolics in the resistance mechanisms of plants against fungal pathogens and insects. In: Imperato F. Phytochemistry: advances in research. Research Signpost 37/661 (2), Fort P.O., Trivandrum-695 023, Kerala, India. pp. 23-67.

Mangaraj S, Singh A, Samuel DVK and Singhal OP 2001. Comparative performance evaluation of different drying methods for chillies. J. Food Sci. Technol. 38(3): 296-299. 
Nkansah MA and Amoako CO 2010. Heavy metal content of some common spices available in markets in the Kumasi metropolis of Ghana. Am. J. Sci. Ind. Res. 1(2): 158-163.

Pal AK, Muduli AK, Jena B and Acharya R 2012. Influence of cadmium on paprika chilli (Capsicum аппиит) and its detoxification by organic amendments. The Madras Agric. J. 99(7-9): 482-484.

Singh S and Devi MB 2015. Vegetables as a potential source of nutraceuticals and phytochemicals: a review. Int. J. Medicine Pharm. Sci. 5(2): 1-14.

Srideepthi R, Krishna MSR, Suneetha P, Srupanika D, Bhavana SVL, Sahitya UL and Kasim DP 2017. Antioxidant potential of chili seedlings against anthracnose. Int. J. Green Pharm. 11(2): S305-S311.

US EPA US Environmental Protection Agency 2010. Integrated Risk Information System.

Velioglu YS, Mazza G, Gao L and Oomah BD 1998. Antioxidant activity and total phenolics in selected fruits, vegetables and grain products. J. Agric. Food Chem. 46: 4113-4117.

Wani AL, Ara A and Usmani JA 2015. Lead toxicity: a review. Interdiscip Toxicol. 8(2): 55-64.

Zhishen J, Mengcheng T and Jianming W 1999. The determination of flavonoid contents in mulberry and their scavenging effects on superoxide radicals. Food Chem. 64: 555-559.

(Manuscript received on 7 October, 2018; revised on 16 September, 2020) 